\title{
舌骨上筋群における嚥下表面筋電図の電極位置の検討
}

\author{
興津 太郎*1 有田元英*1 園田 茂*1 大田哲生*1 \\ 堀田富士子*1 本田哲三*1 千野直一*2
}

\section{The Surface Electromyography on Suprahyoid Muscles during Swallowing}

Taro Okitsu, ${ }^{* 1}$ Motohide Arita, ${ }^{* 1}$ Shigeru Sonoda, ${ }^{* 1}$ Tetsuo Ota, ${ }^{* 1}$ Fujiko Hotta, ${ }^{* 1}$ Tetsumi Honda, ${ }^{* 1}$ Naoichi CHINO*2

\begin{abstract}
The object of this research was to study how to detect most effectively electromyogram (EMG) of suprahyoid muscles during swallowing. The position of recording electrodes on suprahyoid muscles during deglutition has been investigated in 6 healthy men. The EMG of suprahyoid muscles was detected by 4 methods designated as submental, submaxillary, lateral and hyoidal recording at full bite, tongue elevation in 2 seconds and water $3 \mathrm{ml}$ swallowing. The EMG area recorded by each method was divided by recording time $(\mathrm{ms})$ and by inter-electrode distance $(3-10 \mathrm{~cm})$. This parameter was called area $/ \mathrm{cm}(\mu \mathrm{V} \cdot \mathrm{s} / \mathrm{cm})$. The area $/ \mathrm{cm}$ from the submental recording was about twice that from the other 3 methods at tongue elevation and water swallowing. It was concluded that the submental recording could detect the EMG of suprahyoid muscles most effectively and this method might be applicable to a biofeedback training in the rehabilitation for swallowing disorders. (Jpn J Rehabil Med 1998; 35 : 241-244)

要 旨：嚥下口腔期における舌骨上筋群，咀嚼筋の筋電図を記録する表面電極設置部位につ いて検討した. 対象は健常男性 6 名である. 舌骨上筋群について下顎の 4 導出（オトガイ下, 䪽下，外側，舌骨導出）を，咬筋について筋腹中央での導出を設定した。そして最大咬合，舌 挙上最大努力，水矄下に抢ける表面筋電図を記録した。各導出の電極間距離は $3 \sim 10 \mathrm{~cm}$ と差 があるため $1 \mathrm{~cm}$ 当たりの面積（以下，面積）を比較した。舌挙上と水䜩下では， 4 導出の中 でオトガイ下導出の面積が最大であった．従ってオトガイ下導出は舌骨上筋群の筋活動を鋭敏 に記録することができると推察され，今後バイオフィードバック訓練での電極設置部位として 応用が期待された。(リ八医学 $1998 ； 35 ： 241-244$ )
\end{abstract}

Key words: 曣下 (swallowing), 筋電図 (electromyography), バイオフィードバック (biofeedback), 嬩下訓練 (dysphagia rehabilitation)

はじめに

脳卒中を含む中枢神経疾患患者の中に嚥下障害を訴 える患者がしばしば見られ，患者の日常生活上の大き な問題のひとつとなっている. 現在のところ嚥下に対 するリハビリテーションは基本的訓練として発声，咳 払い, 空嚥下, いきみ, 舌運動, 咀嚼などの運動訓練
や口腔, 咽頭へのアイスマッサージ, 酸刺激などの感 覚刺激を用いた嚥下訓練があり，摂食訓練として姿勢 (頸部屈曲など)，食物形態の調整などがある。また評 価法としては嚥下造影検査, 内視鏡検査, 嚥下圧測定 が行われている。

曣下運動は舌の挙上で開始され, 咽頭筋の反射性収 縮に連続する，舌挙上運動を筋電図学的に記録できれ

1997 年 6 月 17 日受付, 1998 年 2 月 4 日受理

*1 東京都リハビリテーション病院リハビリテーション科/テ 131-0034 東京都畦田区堤通 2-14-1

Tokyo Metropolitan Rehabilitation Hospital

*2 慶應義塾大学医学部リハビリテーション医学教室/テ 160-0016 東京都新宿区信濃町 35

Department of Rehabilıtaion Medicine, Ke1o University School of Medicine 
ば舌骨上筋群の強化を目的としたバイオフィードバッ $ク^{11)}$ 訓練への応用が可能である。しかし舌の筋活動に 関して表面筋電図の記録法について検討した報告は検 索した範囲では少ない.

そこで今回我々は，舌骨上筋群の筋活動を記録する 表面電極の設置部位と咬筋活動の影響について研究し たので若干の考察とあわせて報告する。

\section{方法および対象}

歯科口腔外科的に問題のない, 健常男性 6 名 （25４0 歳，平均年歯 32 歳）を対象とした. 実験に は筋電計 (日本光電社製, Neuropack $8^{\circledR}$ ) と, 汎用 されている塩化銀血電極（直径 $7 \mathrm{~mm}$ ）を使用し，舌 骨上筋群と咬筋の筋電図を記録する下顎での 4 導出, 咬筋上での 1 導出の計 5 導出を採用した。周波数帯域 は $3 \mathrm{kHz}$ から $20 \mathrm{~Hz}$ とした。以下，舌骨上筋群を反

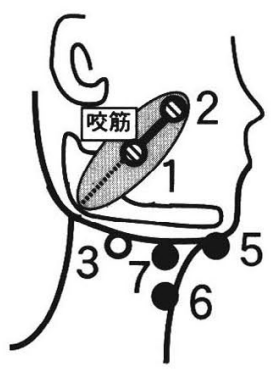

a)

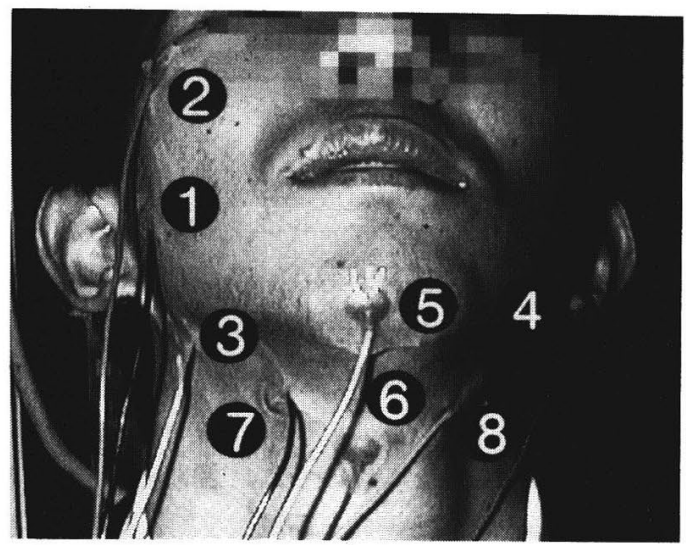

c)

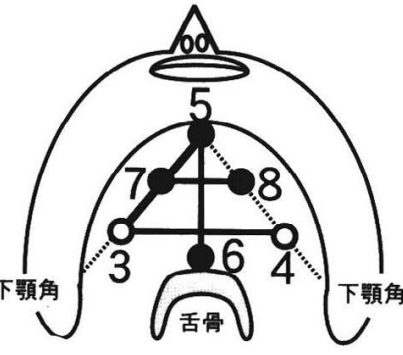

b)
図 1 舌骨上筋群と咬筋における電極設置部位 a）は電極部位を側面から，b）は下顎から見たもの，c）は実 際の写真である、数字は電極番号の位置を示す、咬筋導 出：(1)-(2), 䫟下導出：(3)-(4), 外側導出 : (3)-(5), 舌骨導 出：(5)-(6), オトガイ下導出：(7)-(8)
映する 4 導出，咬筋上での導出（以下，咬筋導出）の 電極配置について説明する。

咬筋の導出は煩骨直上に基準電極（電極 2）を，咬 筋の走行に沿って煩骨と下顎角を結んだ中点, すなわ ち咬筋筋腹中央に記録電極（電極 1) を貼付した（図 1 a).

舌骨上筋群の筋電図は次のように記録した。(1)オ トガイ隆起一下顎角の前 1/3における電極 7-8 間（距 離 $3 \mathrm{~cm}$ ）をオトガイ下導出とした。（2）オトガイ隆 起一下顎角の後 $1 / 3$ における電極 3-4 間（距離 10 $\mathrm{cm}$ )を顎下導出とした。(3) 電極 3-7 間（距離 6 $\mathrm{cm}$ ）を外側導出とした。（4)オトガイ隆起と舌骨前 方を結ぶ電極 5-6 間（距離 $6 \mathrm{~cm}$ ）を舌骨導出とした (図 $1 \mathrm{~b}, \mathrm{c}$ ).

検査：1) 最大咬合 2 秒間，2)舌を硬口蓋にあてて最 大挙上 2 秒間，3) 冷水 $3 \mathrm{ml}$ の嚥下を，それぞれを 4 回施行し，各検查の間に 1 分休鄎を入れた。筋電図波 形の 1 秒当たりの平均面積（以下，面積；単位 $\mu \mathrm{V}$. s）を測定し 4 回の平均を求め, 各導出の電極間距離 で除して単位長さ当たりの面積（以下，面積 $/ \mathrm{cm}$; 単 位 $\mu \mathrm{V} \cdot \mathrm{s} / \mathrm{cm})$ を算出した。そして舌骨上筋群の 4 導 出の比較と咬筋の活動電位の影響について検討した。 統計処理には分散分析とシェッフェの検定を用いた。

\section{結 果}

（1）最大咬合検査：図 $2 \mathrm{a}$ は最大咬合時，咬筋導 出と下顎 4 導出で咬筋筋電図面積を比較したものであ る. 咬筋導出は筋腹上に位置するため最大であった。 咬筋筋活動の下澦への影響（クロストーク）を，下顎 の各 4 導出での面積/咬筋導出での面積の比で比較す ると舌骨導出が $9.4 \%$ と最小で，オトガイ下導出 $15.8 \%$, 顎下導出 $20.8 \%$, 外側導出 $24.6 \%$ とばらつ きがあった。しかし下顎 4 導出間で咬筋筋電面積に統 計的な有意差は見られなかった。

（2）舌挙上検査：図 $2 \mathrm{~b}$ は舌挙上時の面積 $/ \mathrm{cm}$ を 4 導出間で比較したものである. 各導出の平均値は, 顎下導出 $8.0 \mu \mathrm{V} \cdot \mathrm{s} / \mathrm{cm}$, 外側導出 $11.2 \mu \mathrm{V} \cdot \mathrm{s} / \mathrm{cm}$, 舌骨導出 $11.5 \mu \mathrm{V} \cdot \mathrm{s} / \mathrm{cm}$ ，オトガイ下導出 $32.0 \mu \mathrm{V}$ ・ $\mathrm{s} / \mathrm{cm}$ であった。統計的にはオトガイ下導出は顎下導 出に比べて有意に大きかった。オトガイ下導出, 外側 導出および舌骨導出の間に有意差は認められなかっ た。

（3）水勳下検査：図 $2 \mathrm{c}$ は德下時の面積/ $\mathrm{cm}$ を下 


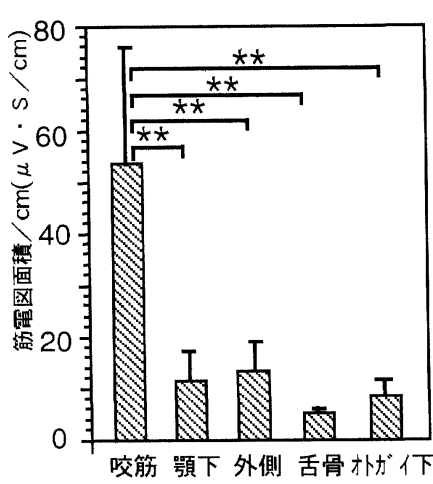

a）最大咬合時

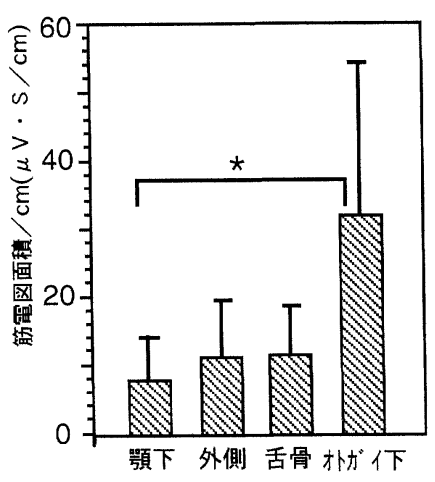

b) 舌挙上時

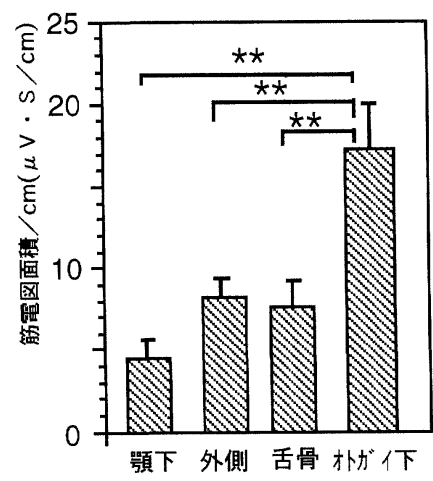

c）嬹 下 時

図 2 各導出に抢ける筋電図面積の比較

$1 \mathrm{~cm}$ 当たりの面積 $(\mu \mathrm{V} \cdot \mathrm{s} / \mathrm{cm})$ を算出し比較した. $\mathrm{a}) \sim \mathrm{c})$ のそれぞれについて筋電図面積を表示した. 棒グラフは単位 長さ当たりの筋電図面積とその標準偏差を示す. 各導出間で有意差を比較した. シェッフェの検定（危険率 $5 \%:{ }^{*} p<$ $005,0.1 \%:{ }^{* *} p<0.001$ )

顎 4 導出間で比較したものである. 各導出の平均值 は, 顎下導出 $4.5 \mu \mathrm{V} \cdot \mathrm{s} / \mathrm{cm}$, 外側導出 $8.2 \mu \mathrm{V} \cdot \mathrm{s} /$ $\mathrm{cm}$, 舌骨導出 $7.6 \mu \mathrm{V} \cdot \mathrm{s} / \mathrm{cm}$, オトガイ下導出 16.6 $\mu \mathrm{V} \cdot \mathrm{s} / \mathrm{cm}$ であった. 統計的にはオトガイ下導出は他 の 3 導出のいずれと比べても有意に大きかった.

\section{考察}

最大咬合時，咬筋筋電面積は舌骨導出で最小であっ た。しかし, 統計学的に下顎 4 導出間で面積に有意差 はなく，咬筋筋活動から受ける影響はどの導出でも同 様と思われる。さらに通常の咀嚼では咬筋最大咬合の 数分の 1 程度の筋力が発揮され, 燕下時は下顎を保持 する程度の咬合力であるため, 咬筋の影響は下顎の 4 導出のいずれにおいてもほとんど問題にならないと推 察された。

舌挙上および㬈下時の筋電図面積/ $\mathrm{cm}$ については, オトガイ下導出は他の導出に比べて 2 倍以上の感度で 筋電を記録することができた. 従って実際にオトガイ 下に電極を設置して舌運動の訓練を行うと, 最も鋭敏 に筋電計の針が振れ, 訓練および評価に利用できるこ とが証明された。また実際の勳下の場面においてもオ トガイ下導出は舌骨上筋群の評価有用であると考え られた。

舌骨上筋群の筋電図を下顎で記録する方法は submental EMGとして紹介されているが2 5), その電極 設置部位について詳細に検討した報告は検索し得た範 囲では見あたらなかった。そこで, 今回, 我々は舌骨 上筋群の活動を簡便に捉える方法について検討した。
本研究で紹介した「オトガイ下導出」の筋電図は, 解 剖学的に舌骨上筋群, すなわち顎舌骨筋 (三叉神経), オトガイ舌骨筋 (舌下神経), 顎二腹筋 (三叉, 顔面 神経), 舌骨舌筋 (舌下神経), 茎突舌骨筋 (顔面神 経）の活動を記録していると推定された。これらの筋 群は, 嚥下の口腔期にほぼ同期して収縮する。そのた め表面電極で個々の筋活動を記録することは困難であ る.曣下に関与する喉頭周囲の筋を針電極を用いて同 定する研究は報告されている ${ }^{4-9)}$. 一方, 舌骨上筋群 各筋に針電極を挿入するのは技術的に可能であるが, 臨床的な評価に応用するのは困難との報告がある ${ }^{10)}$.

オトガイ下導出の電極は左右に配置されており, 顎 舌骨筋の筋走行と一致する。顎舌骨筋は下顎で最も浅 層に位置し, 舌骨上筋群の中で表面積が最大であり, 下頡前方は脂肪が少ないなどの点から，オトガイ下導 出は顎舌骨筋の活動を主に記録していると推測され た. 一方, 他の 3 導出で筋電が低下した原因として, 下顎後方では脂肪や唾液腺などにより電極から筋層ま で距離があり, 筋腱移行部に電極が近接していること や，多方向への走向する筋が集結している点などが挙 ゲられた。

今回紹介したオトガイ下導出により舌骨上筋群の筋 電を検出することは, 訓練の場面では舌挙上, 提舌, 舌回旋など舌運動の強化, 空嬩下や飲水時のバイオフ イードバックに，評価の場面では訓練による回復過程 の観察に利用でき，醸下リハビリテーションの有用な 一手段となると考えられた。 


\section{結語}

舌骨上筋群の筋活動を検出する電極の配置を検討し た結果，下顎 4 導出のうちオトガイ下導出が最も鋭敏 に筋活動を記録できた. 今後, 舌運動の評価や, 筋電 図バイオフィードバックによる摂食嚥下訓練に, 今回 紹介した方法を応用したいと考えている.

本論文の要旨は第 2 回日本リハビリテーション医学会関 東地方会にて発表した。

\section{文献}

1) Bryant $M:$ Biofeedback in the treatment of a selected dysphagic patient. Dysphagia 1991; 6 : 140-144

2) Ertekin C, Pehlivan M, Aydogdu I, Ertas M, Uludag B, Celebi G, Colakoglu Z, Sagduyu A, Yuceyar N . An electrophysiological investigation of deglutition in man. Muscle Nerve 1995; 18: 1177-1186

3) Neils LR, Logemann J, Larson C Viscosity effects on EMG activity in normal swallow. Dysphagia $1994 ; 9$ : 101-106
4) Brunner DP, Duk DJ, Borbely AA: A quantitative analysis of phasic and tonic submental EMG activity in human sleep. Physiol Behav 1990; 48: 741748

5) Paydarfar D, Gilbert RJ, Poppel CS, Nassab PF . Respiratory phase resetting and airflow changes induced by swallowing in humans. J Physiol 1995; 483 (1) $\cdot 273-288$

6) Schultz JL, Perlman AL, VanDaele DJ : Laryngeal movement, oropharyngeal pressure, and submental muscle contraction during swallowing. Arch Phys Med Rehabil 1994; 75 . 183-188

7) Palmer JB, Tanaka E, Siebens AA : Electromyography of the pharyngeal musculature: Technical considerations. Arch Phys Med Rehabil 1989; 70: 283-287

8) Gupta V, Reddy NP, Canilang EP: Surface EMG measurement at the throat during dry and wet swallowing. Dysphagia 1996; 11: 173-179

9) Spiro J, Rendell JK, Gay T : Activation and coordination patterns of the suprahyoid muscles during swallowing Laryngoscope $1994 ; \mathbf{1 0 4} \cdot 1376-1382$

10) Perlman AL. Electromyography and the study of oropharyngeal swallowing Dysphagia 1993;8: 351-355 